\title{
Effect of Filmogen Topical Gel on Pain and Hemorrhage after Tonsillectomy
}

\author{
Jae Hoon Bae, Jang Su Lee ${ }^{(D)}$, Nam Guk Kim, and Hyun Myung Oh \\ Department of Otolaryngology-Head and Neck Surgery, Kwangju Hospital of Christian, Gwangju, Korea \\ 편도절제술 후 통증과 출혈에 대한 투명창상피복제 국소 도포의 효과 \\ 배재훈·이장수·김남국·오현명 \\ 광주기독병원 이비인후과
}

Received January 22, 2019

Revised May 17, 2019

Accepted July 11, 2019

Address for correspondence

Jang Su Lee, MD

Department of Otolaryngology-

Head and Neck Surgery,

Kwangju Hospital of Christian,

37 Yangnim-ro, Nam-gu,

Gwangju 61661, Korea

Tel +82-62-650-5095

Fax +82-62-650-5090

E-mail cielo3797@naver.com

Background and Objectives Tonsillectomy is one of the most common operative procedures in otorhinolaryngology. Most patients following tonsillectomy suffer from postoperative pain and hemorrhage. This study was performed to investigate whether filmogen topical gel (PHARGEL ${ }^{\circledR}$, Vitrobio SAS), applied to the tonsillectomy site after tonsillectomy reduced pain and hemorrhage.

Subjects and Method A total of 40 patients over 15 years old scheduled for elective tonsillectomy were randomly divided into two groups. After tonsillectomy and postoperative day 0 , 1,2 , and 7 , one group was applied with the filmogen topical spray 3-5 times a day but the other group remained without applying it. Pain and postoperative hemorrhage were measured at the postoperative day $0,1,2$, and 7 of the operation. Pain was measured by using a visual analogue scale.

Results Patients who applied the filmogen topical spray presented lower pain scores than patients who didn't applied the spary. There was no difference for postoperative hemorrhage between two groups.

Conclusion Filmogen topical spray is an effective postoperative control for pain but not for hemorrhage on the tonsillectomy site.

Korean J Otorhinolaryngol-Head Neck Surg 2020;63(6):265-9

Key Words Hemorrhage P Postoperative pain · Tonsillectomy.

\section{서 론}

편도절제술은 이비인후과에서 흔히 행해지는 수술 중 하나 로 만성편도염이나 코골이, 수면무호흡증 및 편도비대의 치료 방법으로 시행되고 있다. 1827년 Physicks가 Guillotine법을 소개한 이후 보편적으로 시행되는 수술이나 많은 환자들이 수 술 이후 5일에서 7일까지 장기간의 극심한 통증과 수술 부위 의 출혈로 고통받고 있다. ${ }^{1)}$ 또한 수술 이후에 고통뿐만 아니라 탈수와 부적절한 영양 공급, 스트레스 등을 유발하여 술 후 회

This is an Open Access article distributed under the terms of the Creative Commons Attribution Non-Commercial License (https://creativecommons.org/licenses/by-nc/4.0) which permits unrestricted non-commercial use, distribution, and reproduction in any medium, provided the original work is properly cited.
복을 지연시킬 수 있다. 이에 따라 수술 후 통증을 줄이기 위 해 많은 약제와 방법이 연구되거나 시도되고 있다. ${ }^{2-4)}$ 이 가운 데 최근 사용하기 시작한 외과적 상처 부위에 대한 투명창상 피복제의 국소 도포가 편도절제술 후의 통증 및 출혈 감소에 어떠한 영향을 미치는지에 대한 국내 보고가 아직까지 없었다. 이에 저자들은 투명창상피복제의 국소 도포가 편도절제술 후 통증 및 출혈을 감소시킬 수 있는지 알아보고자 하였다.

\section{대상 및 방법}

\section{대 상}

2018년 6월부터 11월까지 만성편도염으로 양측 편도절제 

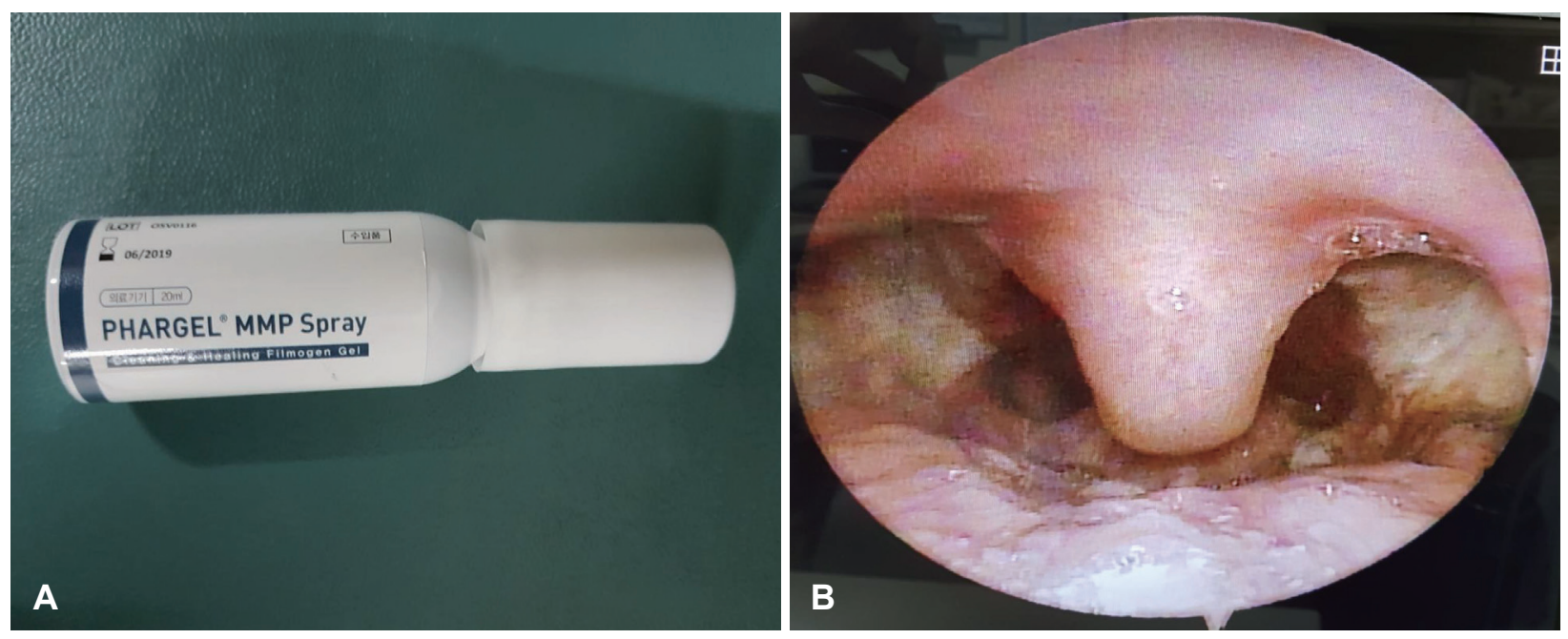

Fig. 1. Picture shows fillomgen topical spray and its application. Filmogen topical spray (A). Tonsillectomy site (B).

술이 예정된 환자 중 통증의 정도를 표현하기에 문제없는 15 세 이상의 환자를 대상으로 하였다. 이 중 혈액응고장애, 간 질환 등 출혈성 질환이 있거나 아스피린 등의 항응고제를 복 용 중인 경우, 꿀 성분 알레르기가 있는 경우, 체질량 지수가 30 이상인 경우 등은 제외하였다. 이러한 포함 기준 및 배제 기준을 적용하여 총 42 명의 환자에 대해 본 연구의 목적 및 방법을 설명하였다.

이 중 수술 관찰 소견에서 편측에 농이 보였던 1명, 양측 편 도와의 손상 정도와 출혈 경향 차이로 지혈을 위해 시행한 전 기 소작술의 정도에 차이가 컸던 1 명을 제외하여 최종 40 명 을 대상으로 전향적 연구(perspective study)를 진행하였다.

본 연구는 광주기독병원 기관생명윤리위원회의 검토와 승 인을 받았다(승인번호: $\mathrm{KCH}-\mathrm{D}-2018-05-003)$.

\section{수술 방법}

모든 환자는 수술 전날 입원하였고, 본 연구에 대해 설명 하고 서면 동의서를 받았다. 수술은 기관 삽관을 통한 전신마 취하에서 동일한 수술자가 동일한 방법으로 Coblation 기구 (EVac 70, ArthroWand, Arthrocare corporation, Sunnyvale, CA, USA)를 사용하여 수술을 시행하였다.

모든 환자를 Rose 자세로 눕히고 Mclvor 개구기를 이용 하여 편도를 노출시키고 Coblator를 이용해 편도를 제거하 는 동시에 지혈 및 소작하였다. 지혈을 위한 전기소작술이 끝 나면 생리식염수로 세척한 후 마른 거즈로 수술 부위를 깨끗 하게 닦아내고 선택된 한 그룹의 환자들에게 투명창상피복 제(PHARGEL ${ }^{\circledR}$, Vitrobio SAS, Issoire, France) 스프레이 를 분무하여 편도 수술 부위에 충분히 도포하였다. 투명창상 피복제는 glycerol, honey, dried fruit extract of vaccinium macrocarpon and vaccinium myrtillus, xanthan gum 등
의 구성성분을 가진다(Fig. 1).

술 후 비스테로이드성 진통제(Loxoprofen $60 \mathrm{mg}$; Lenox ${ }^{\circledR}$, Iidong Pharm, Seoul, Korea; 1일 3회)와 항생제(Cefoperazone sodium 500 mg, Sulbactam sodium 500 mg; Cefola$\operatorname{tam}^{\circledR}$ inj. 1 g, Samjin Pharm, Seoul, Korea; 1일 2회)를 계속 투여하였다. 환자들은 수술 후 2일째에 퇴원하였는데 수술 당일 8시간 후 부터 퇴원 시까지 매일 하루에 총 3 5회에 걸쳐 수술 직후 시행했던 방법과 같은 방법으로 의료인 감독하에 수술 부위에 자가 도포하도록 하였다. 그리고 환자들에게 퇴원 후에도 동일한 방법으로 투명창상피복제를 자가 분무하도록 안내하고 수술 후 7일째에 외래에 내원하도록 하였다.

\section{수술 후 통증}

술 후 통증은 수술 당일 8시간 후, 수술 후 1일, 2일, 7일째 에 Visual Analog Scale(VAS)을 이용하여 전혀 아프지 않으 면 0점, 참을 수 없을 만큼 극심한 통증은 10점으로 하여 환 자 자신들에게 통증을 평가하도록 하였다.

\section{수술 후 출혈}

수술 이후 출혈에 대해서는 술 후 발생한 모든 출혈을 다 포함시켰다. 수술 후 24시간 이내 발생한 일차 출혈과 24시 간 이후 발생한 지연 출혈을 따로 구분하여 조사하였다.

\section{통계학적 분석}

비교 모수는 수술 후 방사성 이통 및 인후두부 통증을 포함 한 통증, 수술 후 출혈로 정하였고, 통계 분석은 SPSS(Stati stical Package for the Social Science, version 18.0 for Windows, SPSS Inc., Chicago, IL, USA)를 이용하였다. 환자군 간 연령 및 편도염 이환 기간에 대한 통계적 분석은 unpaired 
Table 1. Sex, age and duration of tonsillitis among two groups

\begin{tabular}{lccc}
\hline & $\begin{array}{c}\text { Filmogen } \\
\text { topical spray } \\
(\mathrm{n}=21)\end{array}$ & $\begin{array}{c}\text { No filmogen } \\
\text { topical spray } \\
(\mathrm{n}=19)\end{array}$ & $\begin{array}{c}\mathrm{p} \text { - } \\
\text { value }\end{array}$ \\
\hline Sex & 13 & 10 & \\
$\quad$ Male & 8 & 9 & \\
$\quad$ Female & $25.1 \pm 10.0$ & $25.9 \pm 10.3$ & $<0.001$ \\
Age (year) & $18.7 \pm 6.1$ & $17.5 \pm 5.6$ & $<0.001$ \\
$\begin{array}{l}\text { Duration of tonsillitis } \\
\text { (month) }\end{array}$ & & &
\end{tabular}

There was no meaningful difference in patient characteristics including age, duration of tonsillitis between two groups. $p<0.05$ in unpaired t-test

Table 2. Mean VAS pain score after tonsillectomy

\begin{tabular}{lccl}
\hline \multirow{2}{*}{ Variable } & \multicolumn{2}{c}{ VAS score } & \\
\cline { 2 - 3 } & $\begin{array}{c}\text { Filmogen } \\
\text { topical spray }\end{array}$ & $\begin{array}{c}\text { No filmogen } \\
\text { topical spray }\end{array}$ & p-value \\
\hline POD 0 & $5.14 \pm 1.31$ & $6.26 \pm 1.32$ & $<0.001^{*}$ \\
POD 1 & $4.19 \pm 1.29$ & $5.42 \pm 1.22$ & $<0.001^{*}$ \\
POD 2 & $3.10 \pm 1.04$ & $4.89 \pm 1.29$ & $<0.001^{*}$ \\
POD 7 & $2.04 \pm 0.80$ & $3.63 \pm 1.07$ & $<0.001^{*}$ \\
\hline
\end{tabular}

Values are presented as mean \pm standard deviation. $* p<0.05$ in unpaired t-test. POD: post-operative day, VAS: Visual Analog Scale

Table 3. The number of postoperative hemorrhage

\begin{tabular}{|c|c|c|c|}
\hline Variable & $\begin{array}{c}\text { Filmogen } \\
\text { topical spray } \\
\quad(n=21)\end{array}$ & $\begin{array}{l}\text { No filmogen } \\
\text { topical spray } \\
\quad(n=19)\end{array}$ & $p$-value \\
\hline $\begin{array}{l}\text { Primary } \\
\text { hemorrhage }\end{array}$ & 1 & 1 & 1.000 \\
\hline $\begin{array}{l}\text { Secondary } \\
\text { hemorrhage }\end{array}$ & 0 & 1 & 0.475 \\
\hline Total hemorrhage & 1 & 2 & 0.596 \\
\hline
\end{tabular}

t-test로 분석하였다(Table 1). 또한 투명창상피복제의 도포가 통증조절에 효과적인지 알아보기 위한 분석도 unpaired t-test 를 시행하여 수술 당일 8시간 후, 수술 후 1일, 2일, 7일째에 두 군을 비교 분석하였다(Table 2). 한편, 술 후 출혈에 대한 통계 분석에는 Fisher's exact test를 사용하였고 유의 수준은 0.05 로 하였다(Table 3).

\section{결 과}

모든 환자는 무작위로 두 군으로 나누었으며 투명창상피 복제를 도포한 군은 총 21 명으로 남자 13 명, 여자 8 명, 평균 나이는 $25.1 \pm 10.0$ 세, 편도염 이환은 평균 $18.7 \pm 6.1$ 개월이었
다. 한편 투명창상피복제를 도포하지 않은 군은 총 19 명으로 남자 10 명, 여자 9명, 평균나이는 $25.9 \pm 10.3$ 세, 편도염 이환 은 평균 $17.5 \pm 5.6$ 개월이었다. 두 군간에 있어 환자의 연령 및 유병 기간에 대한 분석은 통계학적으로 유의미한 차이를 보 이지 않았다(Table 1).

\section{수술 후 통증}

투명창상피복제를 도포한 환자들과 도포하지 않은 환자들 의 통증 지표는 양측 모두 수술 후 시간이 지나면서 감소하였 지만, 투명창상피복제를 도포한 쪽의 통증 지표가 통계적으 로 유의하게 낮았다. 수술 이후에 각각의 시기별로 수술 당일 8시간 후에 $5.14 \pm 1.31$ 과 $6.26 \pm 1.32(p<0.001)$, 수술 후 1 일째 에 4.19 \pm 1.29 와 $5.42 \pm 1.22(p<0.001)$, 수술 후 2일째에 3.10 \pm 1.04 와 $4.89 \pm 1.29(p<0.001)$, 수술 후 7일째에 $2.04 \pm 0.80$ 과 $3.63 \pm 1.07(p<0.001)$ 로 수술 당일 8시간 후 0일째, 1일째, 2일 째, 7일째 모두에서 투명창상피복제를 도포한 군의 통증 지표 가 그렇지 않은 군에 비해 검사 날짜별로 비교했을 때 통계적 으로 유의하게 낮았다(Table 2).

\section{수술 후 출혈}

술 후 출혈은 일차 출혈이 투명창상피복제를 도포한 군에서 1 예, 도포하지 않은 군에서 1 예 발생하였다. 지연 출혈은 투명 창상피복제를 도포한 군에서 0예, 도포하지 않은 군에서 1예 발생하였고, 두 군 간의 일차 출혈 및 지연 출혈 그리고 모든 출혈에서 통계적으로 유의한 차이를 보이지 않았다(Table 3).

\section{고 찰}

편도절제술은 이비인후과 영역에서 오랫동안 가장 많이 시 행되어왔던 수술 중 하나로 인후두부의 통증과 수술 후 출 혈이 중요한 합병증으로 인식되고 있다. 이러한 합병증은 탈 수, 부적절한 영양공급 등에 의해 신체 내 스트레스를 유발 시키고 회복을 지연시키며 인체에 유해한 영향을 미치게 된 다. 통증에 관한 병태생리 연구들이 진행되면서 술 후 통증 의 기전에 대해서 많은 연구가 이뤄져왔는데, 편도 수술로 인 해 조직이 손상되면 중추감작과 말초감작이 초래되어 과민 한 통증반응을 나타내어 수술 후 통증의 주요 원인이 되어 왔다.5,6) 또한 수술 이후에 편도와의 노출로 생긴 출혈은 일반 적으로 술 후 최초 24 시간 이내 발생하는 일차 출혈과 이후 발생하는 지연 출혈로 구분 짓는데 일차 출혈은 소혈관의 노 출과 부적절한 술기 등에 의해 발생하고, 지연 출혈은 편도와 의 감염, 가피의 박리 등이 원인이 되어 발생한다고 한다. 그 래서 예전부터 수술 후 통증 및 출혈을 줄이기 위한 연구가 
많이 이뤄져 왔고 이러한 방법들로는 비스테로이드성 소염 제, 스테로이드 제제, 아편양제제, 국소 마취제의 분무나 국 소침윤 및 신경 차단 등이 이용되고 있다. ${ }^{5-7)}$ 또한 최근 편도 절제술 후에 편도수술 부위에 시행하는 섬유소 응고제의 국 소 도포가 통증 감소에 도움이 된다고 보고하였다. ${ }^{89}$

최근 투명창상피복제가 구강의 외상 및 외과적 상처 보호 에 사용되는데 이는 글리세롤이 함유된 점성이 있는 피복제 로 창상 부위에 필름을 형성하여 습윤 환경을 만들어 상처 를 깨끗이 하고 감염의 위험을 줄여, 창상을 보호하여 상처 를 회복하는 데 도움을 준다고 알려져 있다. 투명창상피복제 국소 도포를 통한 편도절제술 후 통증 감소 및 출혈 감소에 대한 국내 보고는 아직 없지만 Shrivastava 등 ${ }^{10)}$ 은 alchemilla vulgaris(래이디스맨틀)와 글리세롤 복합제가 구강 내 위 생과 상처 회복에 도움이 준다고 보고하였는데 이 약물은 글리세롤에 의해 얇은 막이 형성이 되고 조직 손상 회복에 도움이 되는 근섬유아세포, 상피세포의 성장을 증진시키고 박테리아 감염을 줄일 수 있다고 보고하였다.

최근 구강 내 염증 및 통증을 줄이는 데 많은 구강 국소 도포제가 개발되었는데 그 중의 하나인 $\mathrm{PHARGEL}{ }^{\circledR}$ 은 구 강 상처 치료제로서 상처회복에 필요한 3가지 요소를 수행 하는 것으로 알려져 있다. 이 투명창상피복제는 상처 표면에 서 용질 분자 또는 이온이 그 주위에 물 분자를 끌어당겨 마 치 막을 형성하는 것과 같은 수화작용에 의해 삼투압 막을 형성한다. 이 삼투압 막은 상처에 있는 오염물질, 박테리아, 죽은 세포들과 불순물을 제거하는 효과가 있으며, 과잉 생산 된 단백질 분해 효소의 작용을 차단해 건강한 세포의 성장 을 촉진시키는 회복 효과가 있다. 또한 이 막은 주위 자극으 로부터 상처 부위를 보호하기 때문에 통증을 완화시키는 진 통 효과까지 지니고 있다. ${ }^{10-12)}$ 이에 의해 편도절제술 후 투명 창상피복제의 도포가 통증 감소에 효과가 있을 것이라고 생 각된다.

본 연구에서 환자의 수가 적다는 점과 $\mathrm{VAS}$ 를 이용한 통증 감소의 파악이 객관화된 도구가 아니라는 점과 편도 수술 시 편도염의 이환 기간 등의 차이에 따라 조직의 유착 정도가 다 르고 출혈 가능성도 높아진다는 점 등 개인별 차이가 있다는 것이 본 연구의 한계점이라고 할 수 있다. 그리고 $\mathrm{Kim}$ 등헤에 의하면 편도절제술 시 Coblation을 사용하면 출혈과 통증이 감소하는 점이 알려져 있는데, 본 연구 역시 모든 편도절제술 에 Coblation을 사용하였으므로 투명창상피복제가 통증 감 소에 효과적임을 나타내는 본 연구 결과에 영향을 미칠 수도 있음을 생각해 볼 수 있겠다. 그렇기 때문에 많은 수의 환자 군에서의 연구가 필요하겠고, 개인별로 편도 수술 부위의 각 각 양측 도포 여부에 따른 출혈 및 통증 감소의 비교가 필요
할 것으로 생각된다. 또한 Coblation이 아닌 다른 기구를 이 용하여 편도절제술을 시행하였을 때 투명창상피복제가 출혈 및 통증 감소에 얼마나 이득이 있는지 비교해야 할 것으로 생각된다.

수술 후 발생한 출혈에 대한 분석에서, 투명창상피복제 도 포군과 비도포군 모두에서 출혈 빈도가 낮아 통계학적 유의 성은 없었다. 이는 연구에서의 환자 수가 적다는 점을 한계점 으로 보여주고 있다. 환자군의 분류에서도 환자의 기저 질환, 생활 환경 등 출혈의 요인이 될 수 있는 사항들을 고려해야 명확한 연구가 이루어질 것이다.

수술 종료 후 수술 부위에 도포한 투명창상피복제는 마취 의사에 의한 구강 및 비강 분비물의 흡인 과정이 있기 때문 에, 도포제의 유지가 어려울 수 있다. 또한, 일반적으로 수술 6시간 후부터 수분 섭취를 하게 되므로 도포제 유지 효과가 줄어들 수 있게 된다. 따라서 환자에 수술 후 3 5회 투명창 상피복제 자가 도포를 의료진 감독하에서 반복 시행하도록 교육하였고 효과 증대를 위해서 도포 후 30 분간 금식을 하 도록 하였다. 도포 과정에 있어 기존의 튜브형에 비해 개선된 분무형 피복제 사용으로 효율성 및 편이성을 높일 수 있었 다. 퇴원 후 재내원 시까지(약 1주) 투명창상피복제 도포를 하 지 않은 경우는 없을 정도로 높은 순응도를 보였다. 이와 관 련하여 도포 횟수의 증가가 통증 및 출혈의 감소에 영향을 끼치는가에 대한 추가 연구가 이뤼진다면 도움이 될 것이다.

\section{Author Contribution}

Conceptualization: Jang Su Lee, Jae Hoon Bae. Data curation: Nam Guk Kim, Jae Hoon Bae. Formal analysis: Jae Hoon Bae, Hyun Myung Oh. Investigation: Nam Guk Kim, Hyun Myung Oh, Jae Hoon Bae. Methodology: Jang Su Lee, Jae Hoon Bae. Project administration: Jang Su Lee, Nam Guk Kim. Resources: Jang Su Lee, Jae Hoon Bae. Software: Hyun Myung Oh, Jae Hoon Bae. Supervision: Jang Su Lee, Nam Guk Kim. Validation: Nam Guk Kim, Jae Hoon Bae. Visualization: Hyun Myung Oh, Jae Hoon Bae. Writing — original draft: Hyun Myung Oh, Jae Hoon Bae. Writing-review \& editing: Jang Su Lee, Jae Hoon Bae.

\section{ORCID}

Jang Su Lee https://orcid.org/0000-0003-0714-9943

\section{REFERENCES}

1) Ha SL, Kang BH, Lee SH, Kim SY, Yoo SJ, Nam SY. Postoperative results in adult patients after tonsillectomy. Korean J Otorhinolaryngol-Head Neck Surg 1999;42(10):1279-83.

2) Kim SH, Jang SG, Park MK, Kim YS. The effect of the topical injection of steroid into the pillar and tonsillar bed on posttonsillectomy morbidity. Korean J Otorhinolaryngol-Head Neck Surg 2004;47(1):1000-3.

3) Zadeh F, Derakhshandeh B, Atigh F. The role of local injection of bupivacaine in the management of pain after tonsillectomy surgery. International Journal of Bioassays 2016:5(1);4697-700.

4) Kim NG, Oh HM, Kim JY, Kim DW, Kim WH, Choi DJ. Comparison of tonsillectomy by conventional dissection, 
electrocautery, laser, and coblation. Korean J OtorhinolaryngolHead Neck Surg 2013;56(12):773-7.

5) Jeon EJ, Park YS, Lee SE, Park CS. Effect of muscle relaxant on post-tonsillectomy pain. Korean J Otorhinolaryngol-Head Neck Surg 2003;46(7):598-601.

6) Lee SK, Hwang SJ, Park YS, Kim MW, Kim KB, CHo JH, et al. Effect of rofecoxib on pain and hemorrhage after tonsillectomy. Korean J Otorhinolaryngol-Head Neck Surg 2004;47(12):1297-301.

7) Barrons RW. Treatment strategies for recurrent oral aphthous ulcers. Am J Health Syst Pharm 2001;58(1):41-50.

8) Stoeckli SJ, Moe KS, Huber A, Schmid S. A prospective randomized double-blind trial of fibrin glue for pain and bleeding after tonsillectomy. Laryngoscope 1999;109(4):652-5.
9) Park DH, Han JH, Jang YJ, Lee SY. Effect of fibrin glue on posttonsillectomy pain. Korean J Otorhinolaryngol-Head Neck Surg 2009;52(7):591-3.

10) Shrivastava R, Cucuat N, John GW. Effects of Alchemilla vulgaris and glycerine on epithelial and myofibroblast cell growth and cutaneous lesion healing in rats. Phytother Res 2007;21(4):369-73.

11) Shrivastava R, John GW. Treatment of Aphthous Stomatitis with topical Alchemilla vulgaris in glycerine. Clin Drug Investig 2006; 26(10):567-73.

12) Sen CK, Gordillo GM, Roy S, Kirsner R, Lambert L, Hunt TK, et al. Human skin wounds: A major and snowballing threat to public health and the economy. Wound Repair Regen 2009;17(6):763-71. 